\title{
Spatial and temporal variation in weather events critical for boreal agriculture: II Precipitation
}

\author{
Pirjo Peltonen-Sainio' ${ }^{1}$ Pentti Pirinen², Hanna M. Mäkelä², Hannu Ojanen³ ${ }^{3}$, Ari Venäläinen² \\ ${ }^{1}$ Natural Resources Institute Finland (Luke), Management and Production of Renewable Resources, Fl-31600 Jokioinen, Finland \\ ${ }^{2}$ Finnish Meteorological Institute, PL 503, FI-00560 Helsinki, Finland \\ ${ }^{3}$ Natural Resources Institute Finland (Luke), Green Technology, FI-31600 Jokioinen, Finland \\ e-mail: pirjo.peltonen-sainio@luke.fi
}

\begin{abstract}
There is great temporal and spatial variation in precipitation in Finland. Both drought episodes and repeated, abundant rains may interfere with crop growth, yield and quality formation, and many agricultural operations (such as tillage, sowing, crop protection and harvesting). The windows for optimal operations are often narrow due to the short growing season and variable weather conditions. Field traffic at high soil moisture may e.g. cause soil compaction. Also, the high environmental footprint on agriculture under high latitude conditions is often attributable to fluctuations in precipitation. The station-wise precipitation observations from the Finnish Meteorological Institute for the time period of 54 years (1961-2014) were interpolated to a regular $10 \mathrm{~km} \times 10 \mathrm{~km}$ grid covering the whole country. Several successive time slices were used to calculate the likelihood of: 1) drought periods and 2) periods with repeated rains with above normal precipitation sum so that both of these lasted for at least a) two weeks or b) three weeks. We demonstrated substantial spatial and temporal variation in the likelihood of drought and repeated rains: drought episodes were common during the early half of the growing season, while again repeated rains with high accumulated precipitation (lasting for two weeks) became common in the latter part of the growing season. Though, we highlighted in this paper some examples of how these events may affect agriculture and their environmental impacts, the datasets published here may be applied for many other assessments.
\end{abstract}

Key words: crop, drought, growing season, heavy rains, probability, spatial variation

\section{Introduction}

In Finland, rainfall is distributed throughout the year with total annual precipitation averaging from approximately $500 \mathrm{~mm}$ in the north to $650 \mathrm{~mm}$ in the south and east (Pirinen et al. 2012). The average annual precipitation in the whole country has varied during the last five decades between $440 \mathrm{~mm}$ (in 1976) and $740 \mathrm{~mm}$ (in 2012), describing the major year-to-year variation in precipitation totals. However, seasonal differences in distribution are also considerable. Summer is the wettest season with an average three-month (June-August) precipitation sum exceeding $200 \mathrm{~mm}$ in most parts of the country. However, the number of rainy days is the highest in autumn (September-November), when the rainfall amounts are nevertheless some tens of millimetres lower than in summer. Spring (March-May) is the driest season, with average precipitation amounts varying around $100 \mathrm{~mm}$. In winter (December-February) average precipitation amounts typically remain between those of spring and autumn (Pirinen et al. 2012).

The distribution of precipitation differs e.g. within the growing season and is often contrary to the requirements of the crops (Peltonen-Sainio et al. 2014). Late spring to early summer is generally characterized as being the less rainy period of the growing season, while again towards the end of the season rains become more frequent (Peltonen-Sainio et al. 2011). In addition to the typical difference in the distribution of rains between and within the seasons, annual variation is high, challenging many of the agricultural operations but also making the farmer's decision making reactive instead of being based on long-term operational strategies. All these are together also drivers for many of the adverse effects of boreal agriculture on environment. On the other hand, the skill in providing short and medium-term weather forecasts has improved steadily over the past few decades (Haiden et al. 2014), and nowadays the provision of different weather forecasting services is ample (Saarikivi et al. 2000). More than from the short-term forecasting, a farmer might benefit substantially from successful seasonal weather forecasts that could provide accurate guidelines of the temperature conditions and the amount and temporal distribution of precipitation during the coming growing season. However, even though the development of seasonal forecasting is of great interest (Doblas-Reyes et al. 2013), the current capabilities of the forecasts are still rather low in the boreal region (Manzanas et al. 2014). 
Depending on the timing of the growing season and how it matches with the most vulnerable growth phases of food, feed and biomass crops, drought may markedly limit growth and yield formation in Finland (Peltonen-Sainio et al. 2011, 2014, 2016a). An old proverb says "it rains directly onto the grain crib". With this proverb farmers refer to rains that take place in early summer. Precipitation deficiency is particularly common during the main yield determination phase, thereby leading to frequent yield losses, which for spring barley (Hordeum vulgare L.) averaged, on the basis of 30 years, from 7 to $17 \%$ depending on region (Peltonen-Sainio et al. 2011). Hence, especially during the main yield determination phase in the early growing season, slight increases in precipitation are likely to be favourable for crop yield, while again repeated rains with an accumulated precipitation sum clearly exceeding the mean values exhibit great and manifold risks for agriculture depending on their timing. They may e.g. increase leaching and erosion (Vagstad et al. 2004, $\varnothing$ ygarden et al. 2014) and cause flooding and lodging (Peltonen-Sainio et al. 2014) as also soil compaction due to field traffic during the period of high soil moisture content (Alakukku et al. 2003, Spoor et al. 2003).

This particular sub-paper of a trilogy concentrates on the spatial and temporal variation in precipitation, which is gridded across Finland for many successive time slices that, as a whole, cover the period prior to the onset of field operations in spring to that beyond harvests and sowings in the autumn. Examples of the contribution of both repeated and abundant rains as well as drought episodes to high latitude agriculture are characterized though not in any way thoroughly: the main idea with this trilogy is to introduce in the light of examples how to apply such a comprehensive data set of climatic variability in Finland in the agricultural sector but also in any other sector benefitting from such information. Thereby, data provided in this paper - with more agriculture-relevant information on precipitation events - complements other documents (Venäläinen et al. 2007, Hohenthal et al. 2014 ) as well as information available in Ilmasto-opas portal (see e.g. http://ilmasto-opas.fi/fi/datat/sateiden-toistuvuustasot; http://ilmasto-opas.fi/fi/ilmastonmuutos/videot-ja-visualisoinnit/-/artikkeli/b4df9633-7e1f-4389-9dd0a0539588f211/visualisoinnit.html\#rankkasateiden-toistuvuus).

\section{Materials and methods}

All meteorological data were based on weather observations made by the Finnish Meteorological Institute (FMI). The dataset was quality checked and stored in the institute's climate database. Station-wise weather observations were interpolated to a regular $10 \mathrm{~km} \times 10 \mathrm{~km}$ grid covering the whole country (Aalto et al. 2013). The time period studied was 54 years (1961-2014). The reference period (1981-2010) was used to calculate deviations from the mean values.

Drought periods were defined as also described in Peltonen-Sainio et al. (2016a). Probabilities (\%) of drought periods lasting 14 days were estimated on the basis of daily precipitation data from mid-April to the end of September. Drought was considered to take place when, within a 14 day period, the total precipitation was $<10 \mathrm{~mm}$ (with no more than four rainy days). The probability was calculated by the following equation:

$100 \times[$ number of accepted years / total number of years $(=54)]$

Frequent rains were defined as also described in Peltonen-Sainio et al. (2016a). The likelihood (\%) of repeated rains was estimated on the basis on daily precipitation data in two ways: 1$)$ at least seven rainy days ( $\geq 0.5 \mathrm{~mm}$ $\left.\mathrm{d}^{-1}\right)$ within a two-week period with no more than two successive rainless days $\left(<0.5 \mathrm{~mm} \mathrm{~d}^{-1}\right)$ and the accumulated precipitation for this two-week period was at least equal to or higher than the monthly mean, and 2) at least 10 rainy days $\left(\geq 0.5 \mathrm{~mm} \mathrm{~d}^{-1}\right.$ ) within a three-week period with no more than two successive rainless days $(<0.5 \mathrm{~mm}$ $\mathrm{d}^{-1}$ ) and the accumulated precipitation for this three-week period was at least 1.5 times the monthly mean. The calculation periods of 14 or 21 preceding days were made up on the $15^{\text {th }}$ and the last day of a month from midApril to the end of September. The probability was calculated as shown in Eq. [1].

\section{Results}

Between and within season variation in precipitation is generally high at high latitudes in Europe. Spells of drought as well as heavy and/or repeated rains are fairly common and vary also depending on the time of the growing season. 
Drought periods lasting two (Figs. 1a and 1b) and even three weeks (Figs. 2a and 2b) were very common in AprilMay. Probabilities of spells of drought lasting for at least two weeks (with no more than a total of $10 \mathrm{~mm}$ accumulated precipitation) ranged from 31 to $70 \%$ during the period prior to sowings in the prime crop production region of Finland. The highest likelihood was in the regions in north-west Finland but also occurred by the end of April in the south-eastern coastal regions. Soon after the period for sowing and seedling emergence, probabilities of drought decreased, being most often less than $20 \%$, but became slightly more frequent again in late September $(\leq 30 \%)$. In general, similar probability patterns were observed for drought spells lasting three weeks, however, often with even slightly greater probabilities. This was attributable to accepting up to $18 \mathrm{~mm}$ of total accumulated precipitation during the three-week drought period, while only $10 \mathrm{~mm}$ was accepted for the two-week drought period.
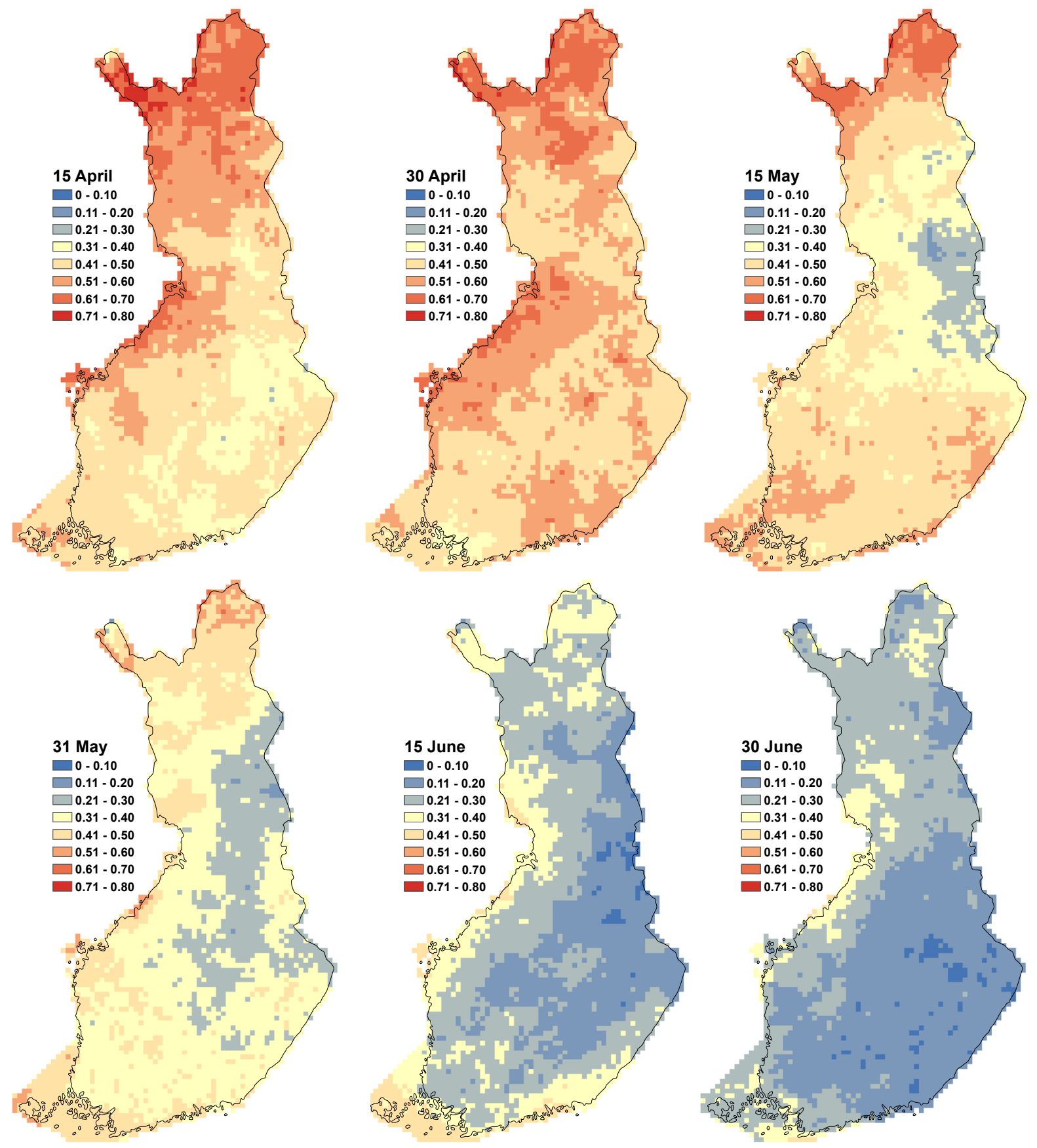

Fig. 1a. Probabilities of drought lasting for at least two weeks for the periods that ended on 15 April to 30 June 

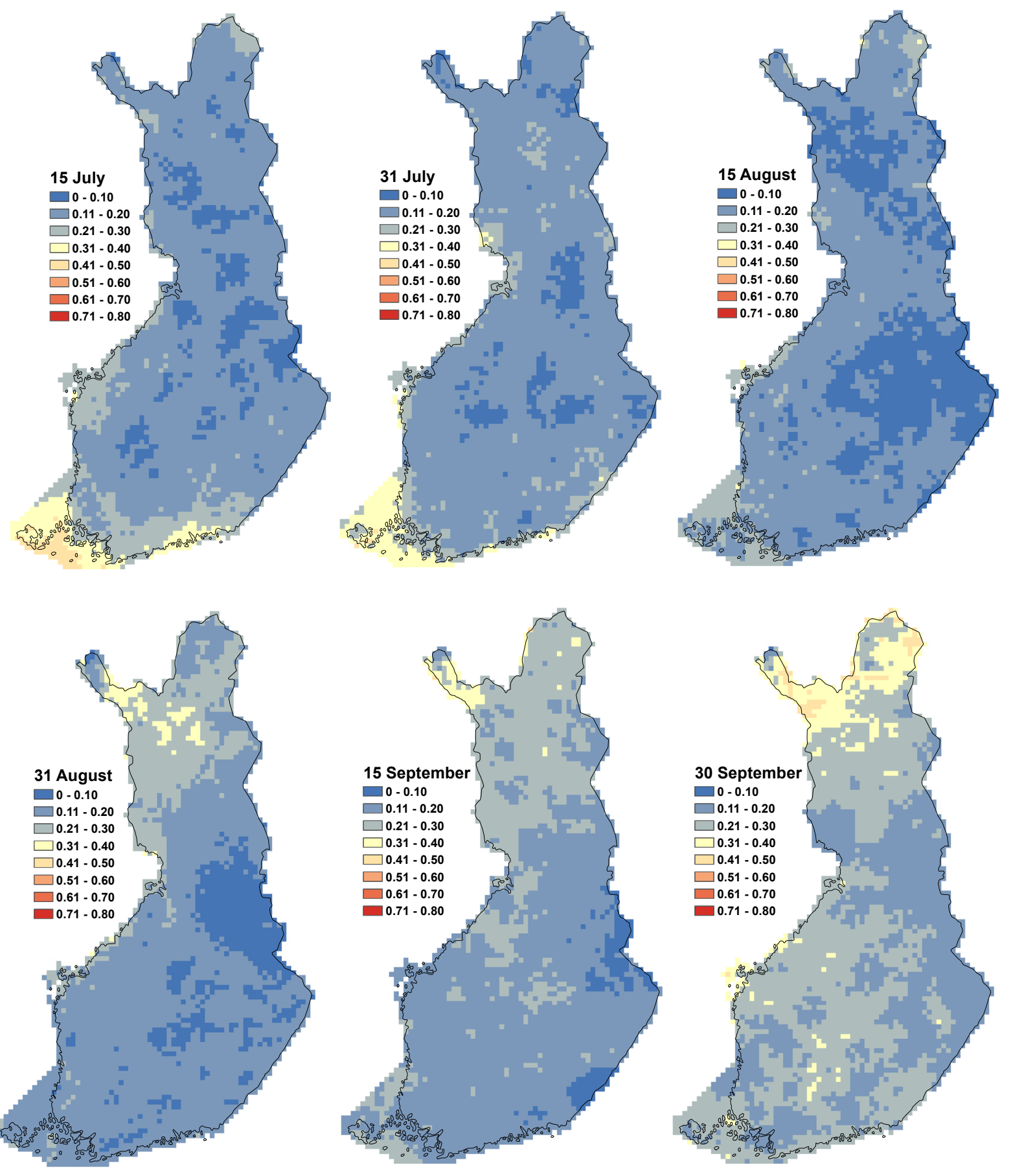

Fig. 1b. Probabilities of drought lasting for at least two weeks for the periods that ended on 15 July to 30 September 

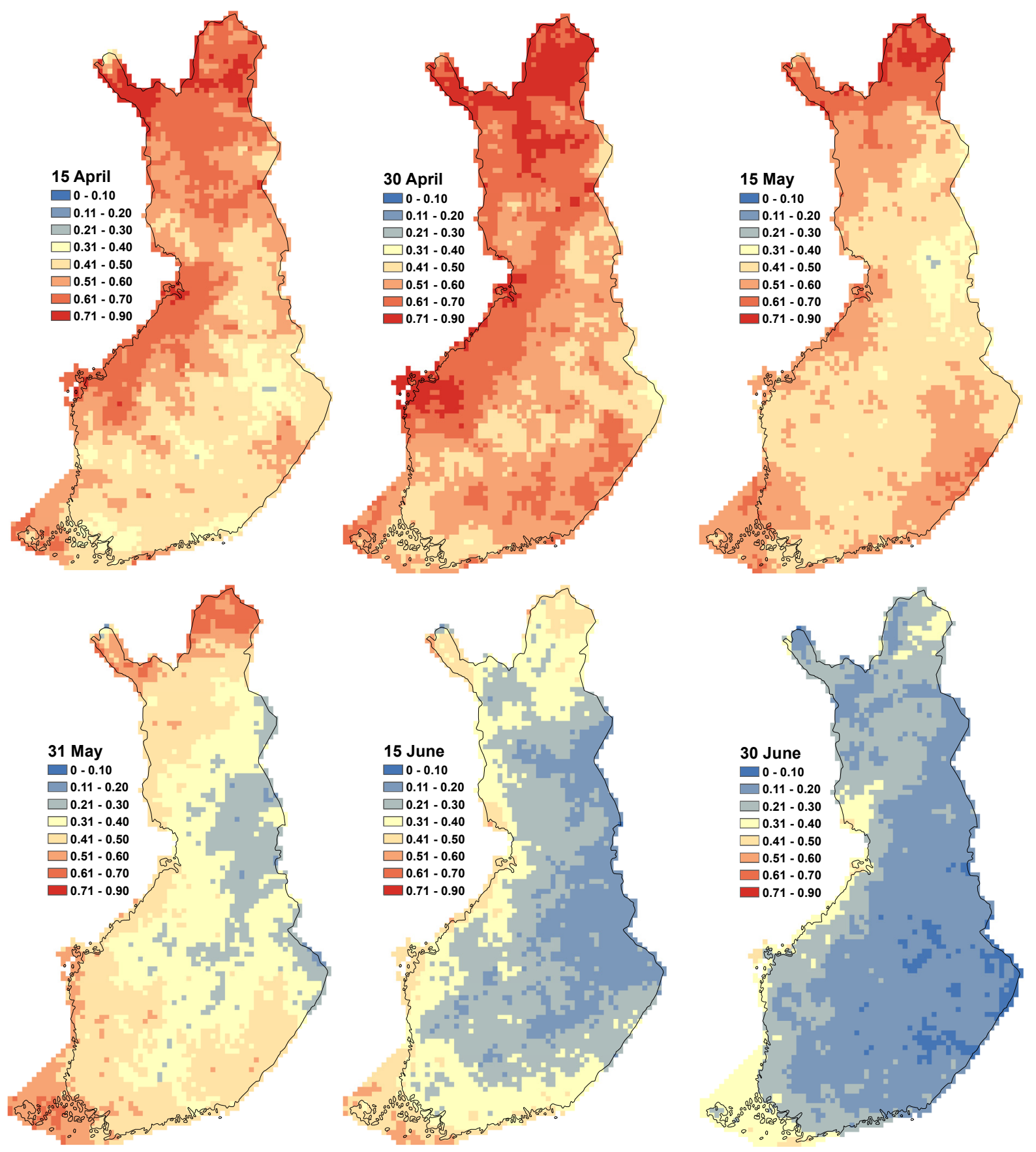

Fig. 2a. Probabilities of drought lasting for at least three weeks for the periods that ended on 15 April to 30 June 

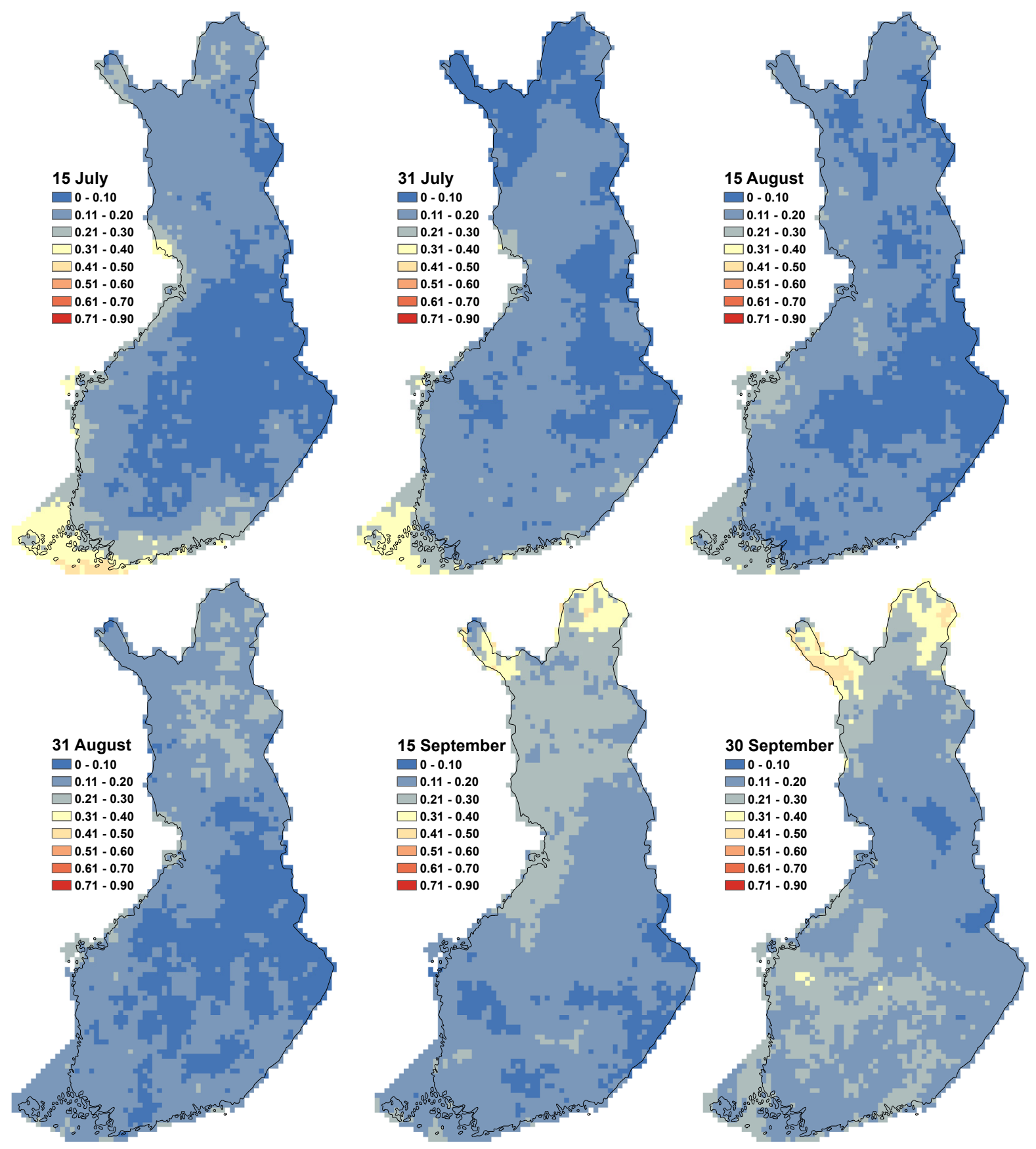

Fig. 2b. Probabilities of drought lasting for at least three weeks for the periods that ended on 15 July to 30 September 
Repeated, abundant rains lasting for at least two weeks were often more probable in the central to northern parts of the country than in the southern parts during the early growing season (Figs.3a and $3 \mathrm{~b}$ ). The likelihoods were usually $6 \%$ at most. The spatial variation ranged markedly from one observation time slice to another, which is attributable to the locational nature of rains during summertime. Repeated rains lasting for two weeks became more frequent again in September, with likelihoods being up to $11 \%$. The likelihood of rains lasting for three weeks was lower (up to 6\%, but mostly 0-3\%) throughout the period from early April to late September (Figs. 4a and 4b), however, with the highest probabilities at the end of September.
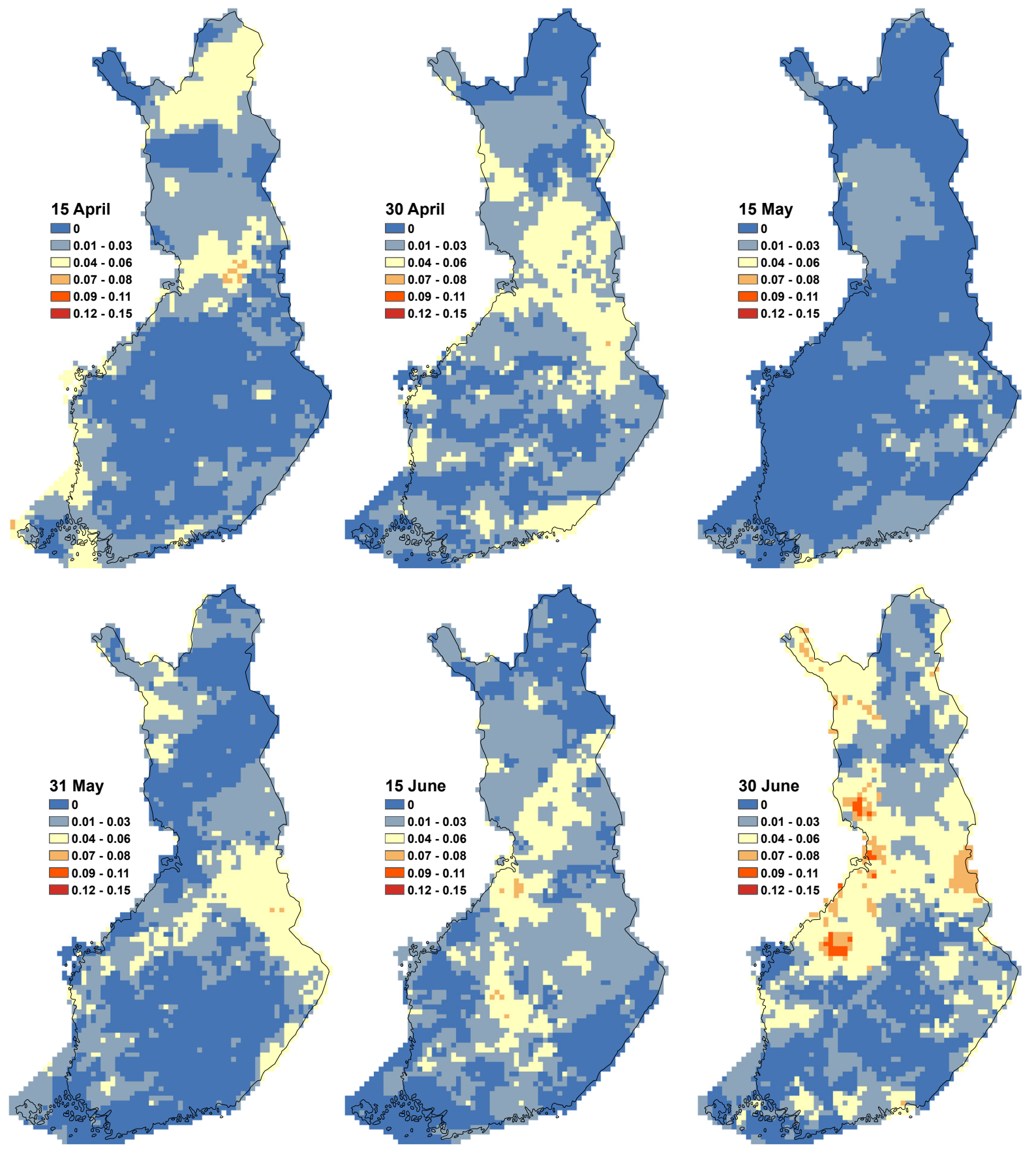

Fig. 3a. Probabilities of repeated rains lasting for at least for two weeks for the periods that ended on 15 April to 30 June 

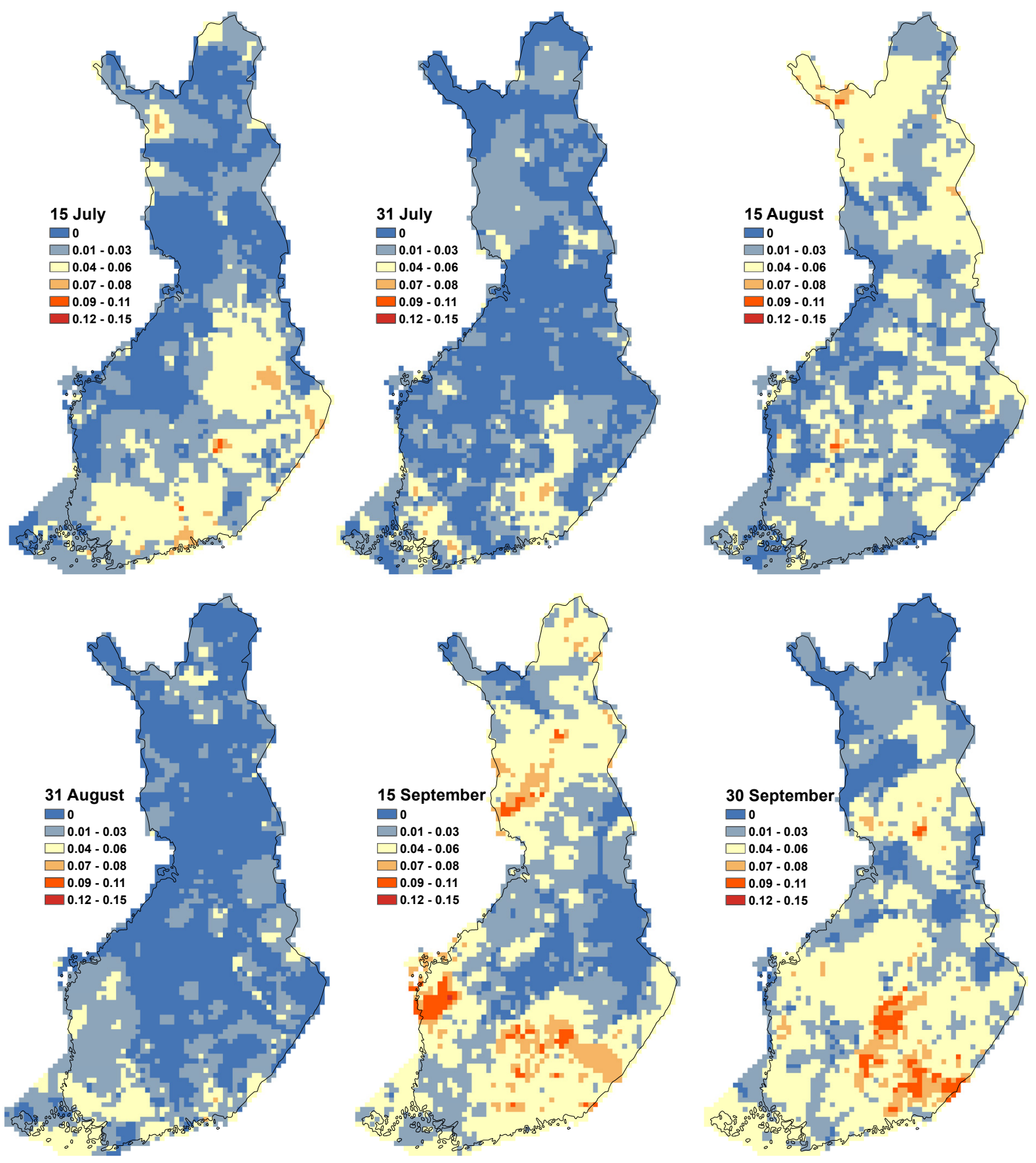

Fig. 3b. Probabilities of repeated rains lasting for at least for two weeks for the periods that ended on 15 July to 30 September 

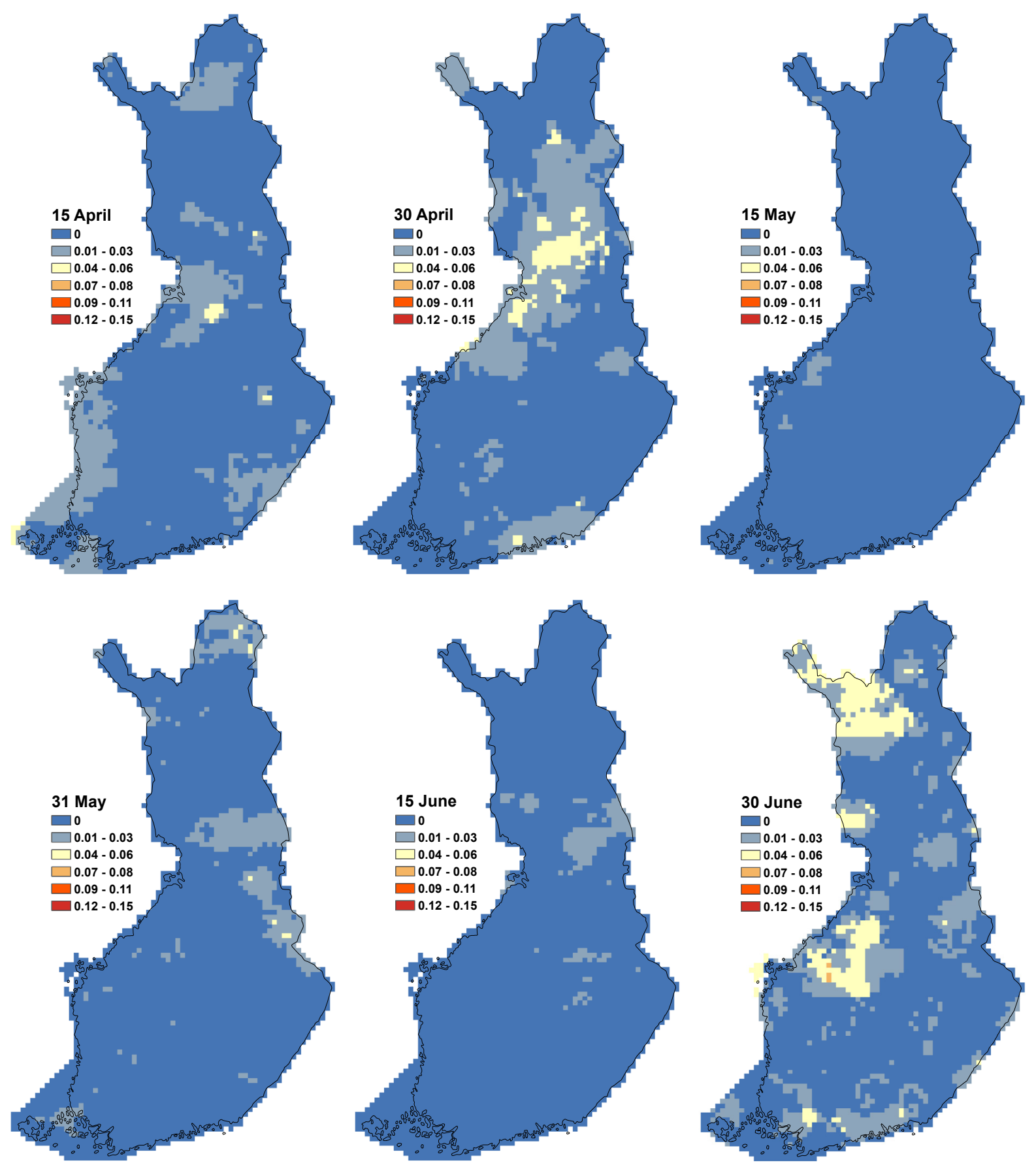

Fig. 4a. Probabilities of repeated rains lasting for at least for three weeks for the periods that ended on 15 April to 30 June 

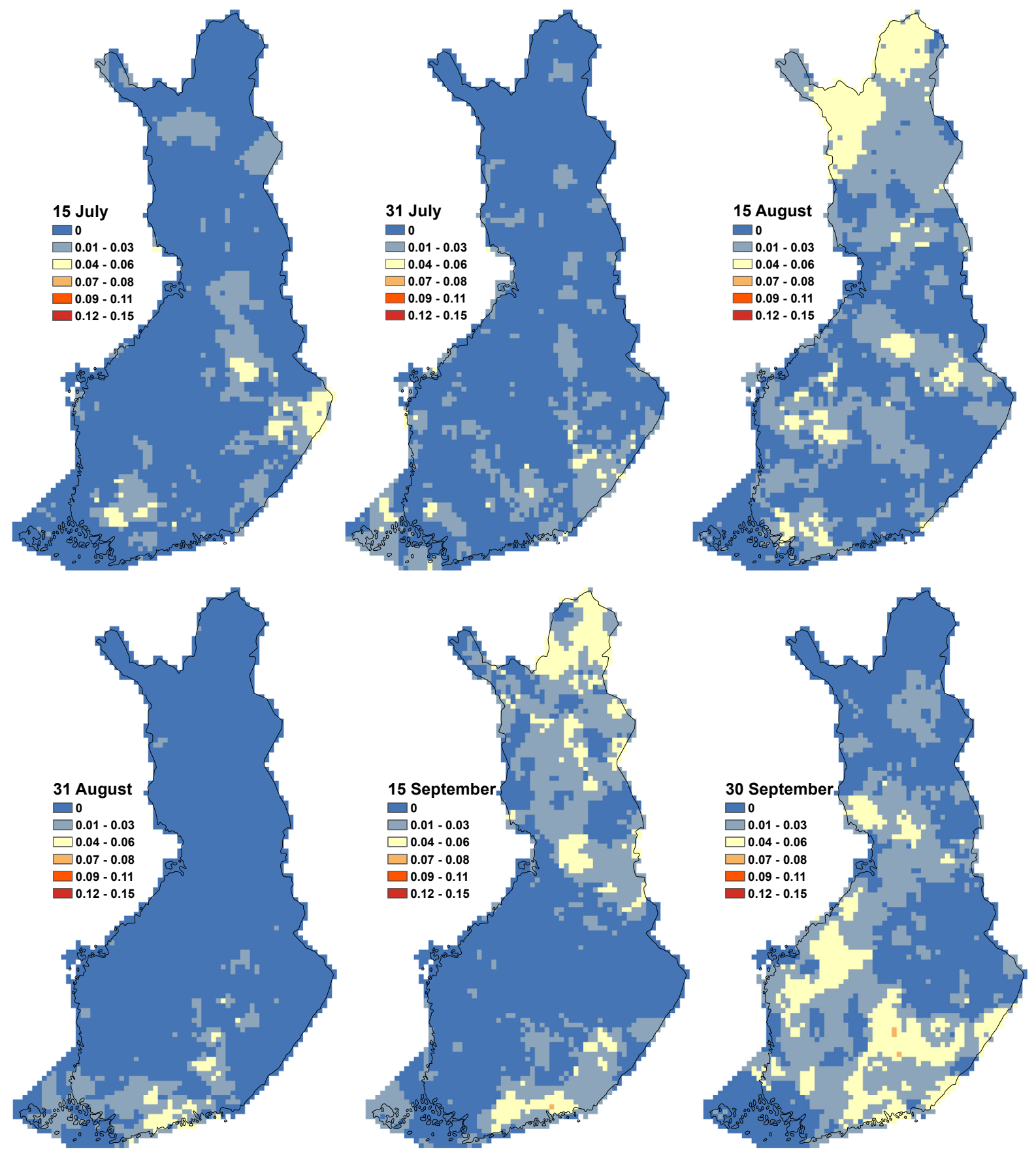

Fig. 4b. Probabilities of repeated rains lasting for at least for three weeks for the periods that ended on 15 July to 30 September

\section{Discussion}

Notable spatial and temporal variation both in the likelihood of having drought episodes or the reverse, having repeated and abundant rains lasting for two or three weeks emphasizes the challenges that highly variable precipitation conditions bring to agriculture in Finland. Impacts of drought and abundant rains on crop production are, however, often dependent on soil conditions like soil type, soil compaction and soil management (Turunen et al. 2015). Even though we concentrate with the following examples on characterizing the general challenges for crop production and its environmental impacts, these comprehensive datasets may also serve many other types of assessments. 
In the short growing season typical of high latitudes, field operations both suffer and benefit from periods with low precipitation. A drought lasting two (Fig. 1a) and even three weeks (Fig. 2a) was very common in April and May with probabilities ranging from 31 to $70 \%$. This means prior to typical sowing times (Peltonen-Sainio and Jauhiainen 2014). Rainless periods enable soil drying after snow melt, which is further facilitated with subsurface drainage that covers some $60 \%$ of Finnish arable land (http://www.salaojayhdistys.fi/tilastot/salaojatilastot.pdf). Depending e.g. on the variation in the thickness of snow cover, the progress of snow melt, depth of soil frost as well as early summer precipitation and temperature, the time for sufficiently dry soil supporting optimal sowing conditions may range a great deal from one growing season to another (Peltonen-Sainio and Jauhiainen 2014). For example, in southern Finland sowings of spring cereals started in late April in some years, but are occasionally postponed even by one month due to insufficient soil drying. Such a range in sowing time is critical when compared to the shortness of the growing season at high latitudes. The greatest likelihood of drought preceding sowing was in the north-west coastal regions of Finland, but also in the more southerly coastal regions and in the southeast of Finland (Figs. 1a and 2a). Due to high variation during sowing time (Peltonen-Sainio and Jauhiainen 2014), drought taking place e.g. by mid-May, may in one year facilitate sowings in the case of late soil drying, while in another year it may, together with elevated temperatures (see Peltonen-Sainio et al. 2016b) cause too fast a soil drying, uneven seedling emergence and plant stand establishment (Mukula and Rantanen 1987, 1989, Pahkala et al. 1994, Hakala et al. 2012). Spring cereals have a very limited capacity to compensate for reduced seedling number by tillering, because long days inhibit tillering (Mela and Paatela 1974, Peltonen-Sainio and Järvinen 1995) and thereby support uniculm plant stands (Peltonen-Sainio et al. 2009). Contrary to this, turnip rape (Brassica rapa L.) and oilseed rape (B. napus L.) may compensate for low number of seedlings per land area by branching without any marked yield losses (Pahkala et al. 1994).

There was a tendency that, soon after the typical period for sowing and/or seedling emergence, the probabilities of drought decreased, usually below $20 \%$ in all regions (Fig. 1a). This sounds to be feasible change when considering that such conditions are in general better for seedling emergence and plant stand establishment. However, according to long-term climatic datasets (30 years), the barley crop gained only 30 to $50 \%$ of the precipitation needed for undisturbed formation of yield potential during the most vulnerable phase of yield determination occurring prior to heading (Peltonen-Sainio et al. 2011). Thereby, the mean yield loss ranged from 7 to $17 \%$ depending on region. Hence, even slight increases in precipitation are likely to favour crop growth when occurring during the yield determination phase (Peltonen-Sainio et al. 2011, Hakala et al. 2012). However, in most regions of the country, the likelihood for frequent rains with an above normal precipitation sum was no more than $3 \%$ in June (Fig. 3a). Pohjanmaa, having large scale cereal and forage production, was an exception, as the likelihood ranged from 4 to $11 \%$. This is likely to contribute reasonably to the crop demand for water in that particular phenological phase, but may also associate with an increased risk of lodging (Mukula and Rantanen 1987). It may also postpone the harvest of forage crops and reduce the total number of cuts. However, the successive time slices differed from each other without showing very consistent trends in changes, which emphasizes the locality of rains that always cause an additional challenge to agricultural operations.

Contrary to drought -which often causes direct yield losses through uneven plant stand establishment, reduced floret and grain set (Rajala et al. 2009, 2011) and associates with inefficient nutrient uptake (Muurinen et al. 2007) - repeated and heavy rains exhibit comprehensive risks for crop growth and agricultural operations depending on their timing. Ironically, also flooding causing anoxia, especially for the particularly sensitive barley crop, is reasonably common (Mukula and Rantanen 1987, 1989). This is, however, often attributable to insufficient infiltration capacity of the soil that may be due to neglected investments in the maintenance of subsurface drainage, which is increasingly common for leased fields with short contract periods (Pouta et al. 2012). Nonetheless, repeated, heavy rains lasting for at least two weeks were often more probable in some northern parts the country than in the southern and inland regions in the early growing season (Fig. 3a). The likelihoods were usually $6 \%$ at most, but these figures do not take into account heavy showers that as such may also cause flooding (Aaltonen et al. 2008).

Repeated rains lasting for two weeks became more frequent again in September with likelihoods being up to $11 \%$, while the likelihood of rains lasting for three weeks was lower, $\leq 6 \%$ throughout the period from April to September (Figs. $4 \mathrm{a}$ and $4 \mathrm{~b}$ ). There are many long-lasting, irreversible and thereby, hazardous impacts that repeated and abundant rains exhibit depending on their timing. One of them is an increased risk of nutrient leaching and erosion (Vagstad et al. 2004, Puustinen et al. 2007, Øygarden et al. 2014). Even though high precipitation-induced runoff and nitrogen $(\mathrm{N})$ loss are typical outside the growing season, extreme events in any season may cause high runoff and nutrient losses ( $\varnothing$ ygarden et al. 2014). When heavy rainfall resulted in delayed sowing of winter wheat, the period of bare soil in the autumn was expanded and thereby, the risk of N loss increased (Børgeson and Olesen 2011). 
Furthermore, soil compaction caused by field traffic (e.g. sowing, harvest, tillage, ploughing, and/or crop protection) during high soil moisture content (Alakukku et al. 2003, Spoor et al. 2003) is detrimental to soil structure, with long-lasting adverse impacts on crop production. The creation of soil compaction and the capacity of the soil structure to recover depend on soil type and texture, crop rotation, tillage system, machinery, soil topography and water outflow pathways (Alakukku et al. 2003, 2010, Turunen et al. 2015). On the other hand, our study also indicated that not only repeated and heavy rains but also drought periods with the opposite impacts became more frequent (being mainly 11-30\%) in September compared to the late summer months (Fig. 1b).

Weather variability may increase and extreme weather events may become more frequent in the future due to climate change (IPCC 2012, 2013). Projected changes in precipitation differ between seasons: for example, precipitation is projected to increase especially outside the growing season while only modest to minor changes are projected to take place during the summer period (Ruosteenoja et al. 2007, Ylhäisi et al. 2010, IPCC 2013). Such anticipated changes do not in any case reduce the risks in agriculture that are discussed above (Peltonen-Sainio et al. 2015a). As Finland is an exceptionally water-rich country, with one third of fields located in direct contact with the shoreline of an inland waterway (Peltonen-Sainio et al. 2015b), the currently challenging and possibly in future growing challenges of drought during the vulnerable developmental phases of crops (Peltonen-Sainio et al. 2015a) can be alleviated with proactive adaptation through the development of irrigation systems currently lacking in Finland (Peltonen-Sainio et al. 2015c). On the other hand, increasing precipitation outside the growing season calls for efficient drainage and year-round water management systems that not only concentrate on irrigation in order to alleviate the impacts of drought but also protect from erosion, nutrient leaching and other adverse impacts on the environment.

\section{Conclusions}

We found substantial spatial and temporal variation in the likelihood of drought episodes and repeated, abundant rain, which highlights the challenges that highly variable precipitation conditions cause for boreal agriculture. Especially drought episodes were common during the early half of the growing season, which is especially critical for crop stand establishment, crop growth and yield formation. Furthermore, repeated rains with high accumulated precipitation that lasted for two weeks became more common in the latter part of the growing season, which again has many impacts on the ripening and quality formation of crops as well as for many agricultural operations having also direct or indirect impacts on environmental footprint of agriculture. Again, we highlighted some examples to characterize the general challenges caused by a great variation in precipitation for crop production and its environmental impacts. However, these comprehensive datasets may serve also many other assessments in agriculture or beyond.

\section{Acknowledgements}

The work was financed by the Ministry of Agriculture and Forestry and Natural Resources Institute Finland (Luke) as a part of a consortium project entitled Improving Resilience to Climate Change and Variation Induced Risks in Agriculture (ILMAPUSKURI).

\section{References}

Aalto, J., Pirinen, P., Heikkinen, J. \& Venäläinen, A. 2013. Spatial interpolation of monthly climate data for Finland: comparing the performance of kriging and generalized additive models. Theoretical and Applied Climatology 112: 99-111.

Aaltonen, J., Hohti, H., Jylhä, K., Karvonen, T., Kilpeläinen, T., Koistinen, J., Kotro, J., Kuitunen, T., Ollila, M., Parvio, A., Pulkkinen, S., Silander, J., Tiihonen, T., Tuomenvirta, H. \& Vajda, A. 2008. Rankkasateet ja taajamatulvat (RATU). The Finnish Environment 31/2008. Natural resources, Finnish Environment Institute. 123 p.

Alakukku, L., Weisskopf, P., Chamen, W.C.T., Tijink, F.G.J., van der Linden, J.P., Pires, S., Sommer, C. \& Spoor, G. 2003. Prevention strategies for field traffic-induced subsoil compaction: a review. Part 1. Machine/soil interactions. Soil \& Tillage Research 73: 145-160.

Alakukku, L., Nuutinen, V., Ketoja, E., Koivusalo, H. \& Kivekäs-Paasonen, M. 2010. Soil macroporosity in relation to subsurface drain location on a sloping clay field in humid climatic conditions. Soil \& Tillage Research 106: 275-284.

Børgeson, C. \& Olesen, J.E. 2011. A probabilistic assessment of climate change impacts on yield and nitrogen leaching from winter wheat in Denmark. Natural Hazards and Earth System Sciences 11: 2541-2553.

Doblas-Reyes, F.J., García-Serrano, J., Lienert, F., Biescas, A.P. \& Rodrigues, L.R.L. 2013. Seasonal climate predictability and forecasting: Status and prospects. Wiley Interdisciplinary Reviews: Climate Change 4: 245-268. 
Haiden, T., Janousek, M., Bauer, P., Bidlot, J., Ferranti, L., Hewson, T., Prates, F., Richardson, D.S. \& Vitart, F. 2014. Evaluation of ECMWF forecasts, including 2013-2014 upgrades. ECMWF Technical Memorandum No.742, 61 p.

Hakala, K., Jauhiainen, L., Himanen, S., Rötter, R., Salo, T. \& Kahiluoto, H. 2012. Sensitivity of barley varieties to weather in Finland. Journal of Agricultural Science 150: 145-160.

Hohenthal, J., Venäläinen, A., Ylhäisi, J.S., Jylhä, K. \& Käyhkö, J. 2014. Occurrence of meteorological summer dry spells and dry days in Northern Europe during the 20th century. Finnish Meteorological Institute Reports 1. 46 p.

IPCC 2012. Summary for Policymakers. In: Field, C.B., Barros, W., Stocker, T.F., Qin, D., Dokken, D.J., Ebi, K.L., Mastrandrea, M.D., Mach, K.J., Plattner, G.-K., Allen, S.K., Tignor, M. \& Midgley, P.M., (eds). Managing the Risks of Extreme Events and Disasters to Advance Climate Change Adaptation. A Special Report of Working Groups I and II of the Intergovernmental Panel on Climate Change. Cambridge: Cambridge University Press. 19 p.

IPCC 2013. Summary for Policymakers. In: Stocker T.F., Qin D., Plattner G.-K., Tignor M., Allen S.K., Boschung J., Nauels A., Xia Y., Bex V. \& Midgley P.M. (eds). Climate Change 2013: The Physical Science Basis. Contribution of Working Group I to the Fifth Assessment Report of the Intergovernmental Panel on Climate Change. Cambridge: Cambridge University Press. 28 p.

Manzanas, R., Fria, M.D., Cofiño, A.S. \& Gutiérrez, J.M. 2014. Validation of 40 year multimodel seasonal precipitation forecasts: The role of ENSO on the global skill. Journal of Geophysical Research: Atmospheres 119: 1708-1719.

Mela, T. \& Paatela, J. 1974. Grain yield of spring wheat and oats as affected by population density. Annales Agriculturae Fenniae 13: $161-167$.

Mukula, J. \& Rantanen, O. 1987. Climatic risks to the yield and quality of field crops in Finland. I. Basic facts about Finnish field crops production. Annales Agriculturae Fenniae 26: 1-18.

Mukula, J. \& Rantanen, O. 1989. Climatic risks to the yield and quality of field crops in Finland. VI. Barley 1969-1986. Annales Agriculturae Fenniae 28: 29-36.

Muurinen, S. 2007. Nitrogen dynamics and nitrogen use efficiency of spring cereals under Finnish growing conditions. University of Helsinki, Department of Applied Biology, Publications 29. 38 p.

Øygarden, L., Deelstra, J., Lagzdins, A., Bechmann, M., Greipsland, I., Kyllmar, K., Povilaitis, A. \& lital, A. 2014. Climate change and the potential effects on runoff and nitrogen losses in the Nordic-Baltic region. Agriculture, Ecosystems and Environment 198: 114-126.

Pahkala, K., Sankari, H. \& Ketoja, E. 1994. The relationship between stand density and the structure of spring rape (Brassica napus L.). Journal of Agronomy and Crop Science 172: 269-278.

Peltonen-Sainio, P. \& Jauhiainen, L. 2014. Lessons from the past in weather variability: sowing to ripening dynamics and yield penalties for northern agriculture in 1970-2012. Regional Environmental Change 14: 1505-1516.

Peltonen-Sainio, P., Jauhiainen, L. \& Alakukku, L. 2015c. Stakeholder perspectives for switching from rainfed to irrigated cropping systems at high latitudes. Land Use Policy 42: 585-593.

Peltonen-Sainio, P., Jauhiainen, L. \& Hakala, K. 2011. Crop responses to temperature and precipitation according to long-term multi-location trials at high-latitude conditions. Journal of Agricultural Science 149: 49-62.

Peltonen-Sainio, P., Jauhiainen, L., Palosuo, T., Hakala, K. \& Ruosteenoja, K. 2015a. Rainfed crop production challenges under Euro-pean high latitude conditions. Regional Environmental Change. DOI:10.1007/s10113-015-0875-1.

Peltonen-Sainio, P., Jauhiainen, L., Rajala, A. \& Muurinen, S. 2009. Tiller traits of spring cereals in tiller-depressing long day conditions. Field Crops Research 113: 82-89.

Peltonen-Sainio, P. \& Järvinen, P. 1995. Seeding rate effects on tillering, grain yield, and yield components of oat at high latitude. Field Crops Research 40: 49-56.

Peltonen-Sainio, P., Laurila, H., Jauhiainen, L. \& Alakukku, L. 2015b. Proximity of waterways to Finnish farmlands and associated characteristics of regional land use. Agricultural and Food Science 24: 24-38.

Peltonen-Sainio, P., Pirinen, P., Mäkelä, H.M., Hyvärinen, O., Huusela-Veistola, E., Ojanen, H. \& Venäläinen, A. 2016b. Spatial and temporal variation in weather events critical for boreal agriculture: I elevated temperatures. Agricultural and Food Science 25: 44-56.

Peltonen-Sainio, P., Rajala, A., Känkänen, H. \& Hakala, K. 2014. Improving farming systems in northern European conditions. In: Sadras VO, Calderini D (eds) Crop Physiology: Applications for Genetic Improvement and Agronomy. Amsterdam, The Netherlands: Elsevier. p. 65-91.

Peltonen-Sainio, P., Venäläinen, A., Mäkelä, H.M., Pirinen, P., Laapas, M., Jauhiainen, L., Kaseva, J., Ojanen, H., Korhonen, P., Huusela-Veistola, E., Jalli, M., Hakala, K., Kaukoranta, T. \& Virkajärvi, P. 2016a. Harmfulness of weather events and adaptive capacity of farmers at high latitudes of Europe. Climate Research 67: 221-240. DOI: 10.3354/cr01378.

Pirinen, P., Simola, H., Aalto, J., Kaukoranta, J.-P., Karlsson, P. \& Ruuhela, R. 2012. Climatological statistics of Finland 1981-2010. Finnish Meteorological Institute Reports 1.83 p.

Pouta, E., Myyrä, S. \& K. Pietola, K. 2012. Landowner response to policies regulating land improvements in Finland: lease or search for other options? Land Use Policy 29: 367-376.

Puustinen, M., Tattari, S., Koskiaho, J. \& Linjama, L. 2007. Influence of seasonal and annual hydrological variations on erosion and phosphorus transport from arable areas in Finland. Soil \& Tillage Research 93: 44-55.

Rajala, A., Hakala, K., Mäkelä, P., Muurinen, S. \& Peltonen-Sainio, P. 2009. Spring wheat response to timing of water deficit through sink and grain filling capacity. Field Crops Research 114: 263-271.

Rajala, A., Hakala, K., Mäkelä, P. \& Peltonen-Sainio, P. 2011. Drought effects on grain number and grain weight at spike and spikelet level in six-row spring barley. Journal of Agronomy and Crop Science 197: 103-112.

Ruosteenoja, K., Tuomenvirta, H. \& Jylhä, K. 2007. GCM-based regional temperature and precipitation change estimates for Europe under four SRES scenarios applying a super-ensemble pattern-scaling method. Climatic Change 81: 193-208. 
Saarikivi, P., Söderman, D. \& Newman, H. 2000. Free Information Exchange and the Future of European Meteorology: A Private Sector Perspective. Bulletin of the American Meteorological Society 81: 831-836.

Spoor, G., Tijink, F.G.J. \& Weisskopf, P. 2003. Subsoil compaction: risk, avoidance, identification and alleviation. Soil \& Tillage Research 73: 175-182.

Turunen, M., Warsta, L., Paasonen-Kivekäs, M., Nurminen, J., Alakukku, L., Myllys, M. \& Koivusalo, H. 2015. Effects of terrain slope on long-term and seasonal water balances in clayey, subsurface drained agricultural fields in high latitude conditions. Agricultural Water Management 150: 139-151.

Vagstad, N., Stålnacke, P., Andersen, H.-E., Deesltra, J., Jansons, V., Kyllmar, K., Loigu, E., Rekolainen, S. \& Tumas, R. 2004. Regional variation in diffuse nitrogen losses from agriculture in the Nordic and Baltic regions. Hydrology and Earth System Sciences 8: 651-662.

Venäläinen, A., Saku, S., Kilpeläinen, T., Jylhä, K., Tuomenvirta, H., Vajda, A., Ruosteenoja, K. \& Räisänen, J. 2007. Sään ääri-ilmiöistä Suomessa. Finnish Meteorological Institute Reports 4. 81 p.

Ylhäisi, J., Tietäväinen, H., Peltonen-Sainio, P., Venäläinen, A., Eklund, J., Räisänen, J. \& Jylhä, K. 2010. Growing season precipitation in Finland under recent and projected climate. Natural Hazards and Earth System Sciences 10: 1563-1574. 